\title{
The Role of Heat Shock Proteins in Alzheimer Disease: A Systematic Review
}

\begin{abstract}
Keywords: Heat shock protein; Neurocognitive disorders; Alzheimer's disease; Dementia

Abstract

Background: Recent studies have shown that heat shock proteins (HSPs) play a role in pathogenesis of Alzheimer's disease.

Objectives: In this review article we investigated the role of HSPs in pathogenesis of cognitive disorders such as Alzheimer's disease.

Data sources: We have reviewed publications from the electronic databases of Medline/PubMed, Scopus, Google Scholar, Embase ISI Web of Knowledge, Biological Abstracts and Chemical Abstracts with keywords of Heat Shock Protein (HSP), Neurocognitive disorders, Alzheimer's disease and Dementia.
\end{abstract}

Study eligibility criteria: After search of data basis with above keywords we found 337 papers published. Then we narrowed our findings to 40 articles and reviewed them.

Results: Results of our study showed that heat shock proteins (HSPS) help refold or degrade mis-folded proteins, reduce abnormal protein accumulation and dysfunction of synapses, neuronal degeneration and gradual and continuous loss of cognitive function in Alzheimer's disease and improves the associated symptoms.

Limitations: We reviewed only some electronic database and other literatures were not reviewed.

Conclusion: Heat shock proteins (HSPs) have significant role in pathogenesis of Alzheimer's disease and other causes of dementia.

\section{Introduction}

Dementia is a disorder that is characterized by impairment of memory and at least one other cognitive function such as aphasia, apraxia, agnosia and loss of executive function. These caused loss of previous level of function [1]. Alzheimer disease (AD) is the most common form of dementia in the elderly, and causes 60 to 80 percent of dementia in elderly [2-4].

Heat shock proteins (HSP) are a group of proteins that impressed by heat shock, the subgroup of these proteins are related proteins functionally take part in the folding and unfolding of other proteins. Their expression is increased in high temperatures or other stress that cells are exposed [5]. The upregulation of the heat shock proteins is important to the heat shock response and is induced by heat shock factor (HSF) [6]. Heat shock proteins are named by their molecular weight. For example, HSP60 has 60 kilodaltons $(\mathrm{kd})$ molecular weight [7].

Recent studies have shown that these proteins have an important role in the pathogenesis of Alzheimer's disease. For example, HSP 70 family has been involved in the pathology of Alzheimer's disease and its major clinical and pathological characteristics like neurofibrillary tangles and $\beta$-amyloid [8-10]. A $\beta$ plaques are important in pathogenesis of Alzheimer's disease and they are mis-folded proteins,
Journal of

Syndromes

\begin{abstract}
Mohammad Reza Najarzadegan ${ }^{1}$, Elham Ataei ${ }^{2}$, Farzad Akbarzadeh ${ }^{3}$, Mahdieh borhani ${ }^{3}$, Naghmeh Mokhber $^{3}$ and Mohammad Kiani ${ }^{{ }^{*}}$
\end{abstract}

${ }^{1}$ Tehran Institute of Psychiatry, Faculty of Behavioral Sciences and Mental Health, Iran University of Medical Sciences, Tehran, Iran ${ }^{2}$ Iranshahr University of medical sciences, Iranshahr, Iran ${ }^{3}$ Psychiatry and Behavioral Sciences Research Center, Faculty of Medicine, Mashhad University of Medical Sciences, Mashhad, Iran

*Address for Correspondence

Mohammad Kiani, Psychiatry and Behavioral Sciences Research Center, Mashhad University of Medical Sciences, Mashhad, Iran, Tel: +989131279365; E-mail: najarzadegan2010@gmail.com

Submission: 06 April, 2016

Accepted: 03 May, 2016

Published: 09 May, 2016

Copyright: (๑ 2016 Najarzadegan MR, et al. This is an open access article distributed under the Creative Commons Attribution License, which permits unrestricted use, distribution, and reproduction in any medium, provided the original work is properly cited.

Reviewed \& Approved by: Dr. Tushar Patil, Department of Neurology, Jawaharlal Nehru Medical College, Wardha, India

because Alzheimer's disease is an example of disorder in proteinfolding [8-10]. HSPs are the important chaperones for reconciliation of proper folding of proteins [11].

On the other hand, small heat shock proteins like HSP27 ubiquitin, a-crystallin, HSP20 and others have chaperone activity, thermotolerance, inhibition of apoptosis, regulation of cell development, and cell differentiation. They also have signal transduction effect [12]. HSP27 provide thermotolerance, cytoprotection, and in time of stressful conditions support the cell survival. HSP27 also works as a chaperone independent with ATP and partially stabilized denatured proteins and also inhibit aggregation of proteins which ensures refolding by the HSP70-complex and involved in the apoptotic signaling pathway. HSP27 interacts with the outer mitochondrial membrane and inhibits the activation of procaspase- 9 [13]. The phosphorylated form of HSP27 inhibits Daxx apoptotic protein and with Fas and Ask1, it prevents the association of Daxx [14].

There is increasing evidence for the involvement of the heat shock proteins family in neurodegenerative disorders. It has been shown that A $\beta$ plaques and HSP70 are localized together [15]. Recent evidence suggests that HSP70 suppresses formation of NFTs with enhanced tau solubility and tau binding to microtubules [16]. Control of the response of cells to stress involving induction of HSPs in differentiated neurons gives a potential therapeutic method to make changes in neuronal proteins that start pathogenic cascades resulting in human neurodegenerative disorders. Given that the etiology of Alzheimer's disease is still unknown, the understanding of HSPs role in Alzheimer's disease and other cognitive disorders can help much more to understanding the etiology and treatment of Alzheimer's disease. In this review article, we investigated the role of proteins in pathogenesis of cognitive disorders such as Alzheimer's disease. 
Citation: Najarzadegan MR, Ataei E, Akbarzadeh F, borhani M, Mokhber N, et al. The Role of Heat Shock Proteins in Alzheimer Disease: A Systematic Review. J Syndromes. 2016;3(1): 6.

\section{ISSN: $2380-6036$}

Table 1: Criteria for Alzheimer's disease (from DSM-IV-TR) [41].

A. Alzheimer's disease is characterized by progressive decline and ultimately loss of multiple cognitive functions, including both:

o Memory impairment-impaired ability to learn new information or to recall previously learned information

o And at least one of the following:

- Loss of word comprehension ability, for example, inability to respond to "Your daughter is on the phone" (aphasia)

- Loss of ability to perform complex tasks involving muscle coordination, for example, bathing or dressing (apraxia)

- Loss of ability to recognize and use familiar objects, for example, clothing (agnosia)

- Loss of ability to plan, organize, and execute normal activities, for example, going shopping

B. The problems in "A" represent a substantial decline from previous abilities and cause significant problems in everyday functioning.

C. The problems in "A" begin slowly and gradually become more severe.

D. The problems in "A" are not due to:

o Other conditions that cause progressive cognitive decline, among them stroke, Parkinson's disease, Huntington's chorea, brain tumor, etc.

o Other conditions that cause dementia, among them hypothyroidism, human immunodeficiency virus infection, syphilis, and deficiencies in niacin, vitamin $\mathrm{B}_{12}$, and folic acid

E. The problems in "A" are not caused by episodes of delirium.

F. The problems in "A" are not caused by another mental illness: Depression, schizophrenia, etc.

Criteria for diagnosis of probable Alzheimer's disease (From DSM-IV-TR)

Dementia established by clinical examination, documented by a standard test of cognitive function (e.g. Mini-Mental State Examination, Blessed Dementia Scale, etc.), and confirmed by neuropsychological tests

Significant deficiencies in two or more areas of cognition, for example, word comprehension and task-completion ability

Progressive deterioration of memory and other cognitive functions

No loss of consciousness

Onset from age 40 to 90 , typically after 65

No other diseases or disorders that could account for the loss of memory and cognition

A diagnosis of probable Alzheimer's disease is supported by:

Progressive deterioration of specific cognitive functions: Language (aphasia), motor skills (apraxia), and perception (agnosia)

Impaired activities of daily living and altered patterns of behavior

A family history of similar problems, particularly if confirmed by neurological testing

The following laboratory results:

Normal cerebrospinal fluid (lumbar puncture test)

Normal electroencephalogram (EEG) test of brain activity

Evidence of cerebral atrophy in a series of computed tomography (CT) scans

Other features consistent with Alzheimer's disease:

Plateaus in the course of illness progression

CT findings normal for the person's age

Associated symptoms, including depression, insomnia, incontinence, delusions, hallucinations, weight loss, sex problems, and significant verbal, emotional, and physical outbursts

Other neurological abnormalities, especially in advanced disease, including increased muscle tone and a shuffling gait

Features that decrease the likelihood of Alzheimer's disease:

Sudden onset

Such early symptoms as seizures, gait problems, and loss of vision and coordination

\section{Methods}

All published studies concerning HSP and Neurocognitive disorders and Alzheimer disease were included from 1970 until 2014 January. Publications were identified from the following electronic databases: Medline/PubMed, Scopus, Google Scholar, Embase, ISI Web of Knowledge, Biological Abstracts and Chemical Abstracts.

\section{Study eligibility criteria}

To include all of studies in electronic databases, keywords such as Heat Shock Protein (HSP); Neurocognitive disorders; Alzheimer disease; Dementia were used. After search of database with above keywords we found 337 papers published. Then we narrowed our findings to 40 articles and reviewed them. Subsequently, the 
Citation: Najarzadegan MR, Ataei E, Akbarzadeh F, borhani M, Mokhber N, et al. The Role of Heat Shock Proteins in Alzheimer Disease: A Systematic Review. J Syndromes. 2016;3(1): 6.

ISSN: $2380-6036$

Table 2: Results of studies on role of HSPs in Alzheimer disease and other causes of dementia

\begin{tabular}{|c|c|c|c|c|}
\hline Author & $\begin{array}{l}\text { Year of } \\
\text { Publish }\end{array}$ & $\begin{array}{l}\text { Heat Shock } \\
\text { Protein } \\
\text { (HSP) }\end{array}$ & Result of Study & $\begin{array}{c}\text { Reference } \\
\text { number }\end{array}$ \\
\hline \multirow[t]{2}{*}{ Brown et al. } & \multirow[t]{2}{*}{2007} & HSP70 & $\begin{array}{l}\text { - Overexpression of HSP70 reduced ischemic injury and protects motor spinal cord } \\
\text { neurons and degeneration of the motor cortex. } \\
\text { A set of HSPs in differentiated neurons cultivated in tissue were expressed by } \\
\text { a neurodegenerative disease countering agent who proved to be a promising } \\
\text { candidate. } \\
\text { - Selective overexpression of HSP70 enhanced the level of synaptic protection. }\end{array}$ & \multirow[t]{2}{*}[17]{} \\
\hline & & HSP40 & $\begin{array}{l}\text { In those areas of the brain which are rich in term of synapse, constitutively } \\
\text { expressed Hsc70 was increased. Hsc70 relates to HSP40 for creating complexes } \\
\text { with the ability to refold denatured proteins. Neurons are able to tolerate stress not } \\
\text { only due to their own HSPs but also by the help of HSPs belonging to their neighbor } \\
\text { glial cells. }\end{array}$ & \\
\hline Wyttenbach A et al. & 2002 & HSP27 & $\begin{array}{l}\text { - HSP27 managed to halt the death of polyglutamine [poly }(\mathrm{Q})] \text { without any } \\
\text { - } \mathrm{HSP} 27 \text { is able to take some measures to reduce probability of death caused via cell } \\
\text { mediation by poly (Q), for example it can lock cytochrome c and ban mitochondrial } \\
\text { death pathway, or employ some protection forms in face of reactive oxygen species } \\
\text { (ROS). } \\
\text { - Since ROS was decreased y HSP27 in cells expressing mutant Huntongton, it } \\
\text { can be concluded that HSP27 actually proves useful in protecting cells faced with } \\
\text { oxidative stress. } \\
\text { Poly(Q) mutation can generate ROS which is capable of direct interference leading } \\
\text { to death of a cell. This is while HSP27 is against such process. }\end{array}$ & [18] \\
\hline $\begin{array}{l}\text { Wilhelmus MM } \\
\text { et al. }\end{array}$ & 2006 & $\begin{array}{c}\text { HSP20 } \\
\text { HSPB2/B3 }\end{array}$ & $\begin{array}{l}\text { - Inside the brains of people suffering from Alzheimer, we can witness a co-habitation } \\
\text { of HSP20 and HSPB2/B3 with Abeta deposition in senile plaques as well as cerebral } \\
\text { amyloid angiopathy. } \\
\text { Except for HSPB2/B3, HSP20, HSP27 and alphaB-crystallin border with Abeta (both } \\
\text { D-Abetal-40 and Abetal-42) and work for reduction or complete prevention of an } \\
\text { attack towards mature fibrils by D-Abeta1-40. } \\
\text { - HSPs may regulate Abeta aggregation and act as an adversary to prevent Abeta } \\
\text { from performing its biological duties, though the amount of interplay between them is } \\
\text { based on the type of HSPs and Abeta peptide. }\end{array}$ & {$[19]$} \\
\hline Ding $Q$ et al. & 2001 & human HDJ-1 & $\begin{array}{l}\text { - HDJ-1 displayed similar degrees of reactive oxygen species (ROS) formation } \\
\text { following oxidative stressors, } \\
\text { HDJ-1 is a great preservative of mitochondrial function and proteasomal activity } \\
\text { following oxidative injury. } \\
\text { Cells transfected with HDJ-1 were more resistant to the toxicity associated } \\
\text { with proteasome inhibitor application. } \\
\text { heat shock proteins may confer resistance to oxidative stress, by } \\
\text { preserving proteasome function }\end{array}$ & [20] \\
\hline $\begin{array}{l}\text { Lowenstein DH } \\
\text { et al. }\end{array}$ & 1994 & HSP72 & $\begin{array}{l}\text { - mRNA for calbindin-D28K, grp78, and HSP72 increased in the hippocampus } \\
\text { following seizures. } \\
\text { The increases in HSP72 and grps indicate the occurence of a generalized stress } \\
\text { response. }\end{array}$ & [21] \\
\hline Luo W et al. & 2007 & HSP90 & $\begin{array}{l}\text { Inhibition of HSP90 in cellular and mouse models of tauopathies leads to a reduction } \\
\text { of the pathogenic activity of cyclin-dependent protein kinase 5, WT Tau protein and } \\
\text { results in elimination of aggregated Tau. } \\
\text { HSP90 played important roles by in maintaining and facilitating the } \\
\text { degenerative phenotype in Neurodegenerative diseases. }\end{array}$ & {$[22]$} \\
\hline Li CY et al. & 2000 & HSP70 & $\begin{array}{l}\text { - HSP70 has been shown to act as an inhibitor of apoptosis. } \\
\text { HSP70 acts as a strong suppressor of apoptosis } \\
\text { acting downstream of cytochrome c release and upstream of caspase- } 3 \text { activation. }\end{array}$ & [23] \\
\hline
\end{tabular}


Citation: Najarzadegan MR, Ataei E, Akbarzadeh F, borhani M, Mokhber N, et al. The Role of Heat Shock Proteins in Alzheimer Disease: A Systematic Review. J Syndromes. 2016;3(1): 6.

ISSN: $2380-6036$

\begin{tabular}{|c|c|c|c|c|}
\hline $\begin{array}{l}\text { Wilhelmus MM } \\
\text { et al. }\end{array}$ & 2006 & $\begin{array}{l}\text { HSP20, } \\
\text { HSP27 } \\
\text {,HSPB2 }\end{array}$ & $\begin{array}{l}\text { - HSP20, HSP27 and HSPB2 were expressed in classic senile plaques, and HSP20 } \\
\text { expression in diffuse senile plaques. } \\
\text { - HSPB2 was expressed in cerebral amyloid angiopathy. } \\
\text { - HSP20, HSP27 and HSPB2 may be involved in the pathogenesis of either senile } \\
\text { plaques or cerebral amyloid angiopathy in AD. }\end{array}$ & [24] \\
\hline Perez $\mathbf{N}$ et al. & 1991 & $\begin{array}{c}\text { HSP } 72, \text { HSP } \\
73\end{array}$ & $\begin{array}{l}\text { Postmortem cortical tissues from Alzheimer's disease cases were found to contain } \\
\text { significantly higher levels of the heat shock proteins HSP } 72 \text { and HSP } 73 \text { than } \\
\text { control cortical tissues. } \\
\text { Induction of HSP } 72 \text { and HSP } 73 \text { is associated with Alzheimer's disease and that } \\
\text { cotranslational processes are affected by this induction. }\end{array}$ & [25] \\
\hline Magrané $\mathrm{J}$ et al. & 2004 & HSP 70 & $\begin{array}{l}\text { - One of the widely recognized early symptoms of Alzheimer disease (AD) is the } \\
\text { accumulation of intracellular beta-amyloid } 42 \text { or (Abeta42). } \\
\text { Expression of Abeta42 encouraged rapid generation of HSP70 proteins in neurons } \\
\text { and protected HSP70 overexpression neurons which were rescued from poisonous } \\
\text { effects of accumulation of intercellular Abeta. }\end{array}$ & [15] \\
\hline Hamos JE et al. & 1991 & $\begin{array}{l}\text { HSP72, } \\
\text { GRP78 }\end{array}$ & $\begin{array}{l}\text { - Major changes occurred for HSP72 and GRP78 during expression in AD. } \\
\text { In AD patients, particularly in nutritic plaques and neurofibrillary tangles of them. A } \\
\text { drastic increase of HSP72 was observed. } \\
\text { An increase of GRP78 was observed in AD, albeit solely in normal neurons which } \\
\text { cytologically stayed intact. In particular in the CA3 subfield of the hippocampus and } \\
\text { deeply-located layers of entorhinal cortex. }\end{array}$ & [26] \\
\hline Castegna A, et al. & 2002 & $\begin{array}{c}\text { DRP-2, HSC- } \\
71\end{array}$ & $\begin{array}{l}\text { Protein } 2 \text { (DRP-2), which is associated with dihydropyrimidinase, indicates a form of } \\
\text { contribution for incapacitated mechanism of the formation of neural network in AD. } \\
\text { It was found out that the cytosolic enzyme alpha-enlase is a target of } \\
\text { proteinoxidation which, in case of occurrence of pathological Ads, is involved in } \\
\text { glycolitic pathway. } \\
\text { Increased level of oxidation in AD brain was revealed by the heat shock cognate } 71 \\
\text { (HSC-71). }\end{array}$ & [27] \\
\hline
\end{tabular}

therapeutic approaches to Alzheimer disease and the role of HSPs were analyzed.

The criteria for Alzheimer disease are shown in Table 1.

\section{Results}

We investigated the previous studies on role of HSPs in Alzheimer disease and other causes of dementia. The results are shown in Table 2.

\section{Discussion}

Alzheimer's disease is a progressive neurodegenerative disorder characterized by loss of memory and cognition and by pathological lesions such as senile plaques, cerebral amyloid angiopathy and neurofibrillary tangles, predominantly consisting of the incorrectly folded proteins amyloid-beta and tau respectively [24]. Amyloid-beta peptide is a main element of senile plaques and has an important role to pathogenesis of the disease [28]. The heat shock proteins constitute molecular chaperones able to act with proteins that are folded incorrectly. It has been shown that impaired protein folding and related decrease in protein function is important factor in the process of neurodegeneration [27]. HSPs play some other roles in the body. For example HSP70 acts as a damage-associated molecular pattern; activates and regulates signaling cascades $[29,30]$ and acts on neurons and numerous cell types. We reviewed the literature role of proteins in the pathogenesis of cognitive disorders such as Alzheimer's disease.

This review showed that expression of HSP can be related to the severity and duration of symptoms of Alzheimer's disease. Study of Renkawek et al. showed the highest expression of wherever rich in terms of senile plaques, Hirano bodies, neurofibrillary tangles as well as in some hippocampal neurons, degenerative astrocytes demonstrated the highest expression of HSP27 [31]. Also, severity of $\mathrm{AD}$ and period of lasting dementia led to an increase of HSP27 expression. Thus we can conclude that higher expression of HSP27 is related to $\mathrm{AD}$ pathology, especially in astrocytes.

It is proved that HSPs make some contributions to neuronal survival and communication which exists between glial cells and neurons. In a study by May et al. it was found that glial cells are capable of providing HSP70 to neurons and that when faced with stress, neurons have a limited ability to generate HSP70 [32]. The ability of HSPs to defend nervous system against various stress and neurodegenerative diseases was known previously [33-35]. Another study by Guzhova et al. showed that it is possible to transfer HSP70 from adjacent glial cells to axons, it was also revealed that extracellular HSP70 is able to defend motor neurons [36]. Additionally, a study by Prahlad V et al. indicated that heat-sensing neurons would prevent heat shock response to be implanted with chronic stress. Moreover, HSP70 not only saves vital components of the cell, but also saves the cell in general [37]. It hampers apoptosis and raises the chances of cells' survival along with improving cell's proteins integration $[38,39]$.

The study of Hoshino et al. showed that HSPs caused expression of a growth factor that activates phagocytosis by microglia named A-degrading enzyme that is a marker of microglial activation and it increased overexpression of reduced plaque formation and neuronal and synaptic loss in Alzheimer's disease [40,41]. 
Citation: Najarzadegan MR, Ataei E, Akbarzadeh F, borhani M, Mokhber N, et al. The Role of Heat Shock Proteins in Alzheimer Disease: A Systematic Review. J Syndromes. 2016;3(1): 6.

ISSN: $2380-6036$

\section{Limitations}

We reviewed only some electronic database and other literatures were not reviewed.

\section{Conclusion}

This review showed that heat shock proteins (HSPs) help refold or degrade mis-folded proteins, reduce abnormal protein accumulation and synaptic dysfunction, neuronal degeneration and cognitive decline in Alzheimer's disease and improves the associated symptoms.

\section{References}

1. Aprahamian I, Stella F, Forlenza OV (2013) New treatment strategies for Alzheimer's disease: is there a hope? Indian J Med Res 138: 449-460.

2. Balin BJ, Hudson AP (2014) Etiology and pathogenesis of late-onset Alzheimer's disease. Curr Allergy Asthma Rep 14: 417.

3. Zhao E, Tranovich MJ, Wright VJ (2014) The role of mobility as a protective factor of cognitive functioning in aging adults: a review. Sports Health 6: 6369.

4. Evans E, Bhardwaj A, Brodaty H, Sachdev P, Draper B, et al. (2013) Dementia in people with intellectual disability: insights and challenges in epidemiological research with an at-risk population. Int Rev Psychiatry 25 : 755-763.

5. De Maio A (1999) Heat shock proteins: facts, thoughts, and dreams. Shock 11: $1-12$

6. Wu C (1995) Heat shock transcription factors: structure and regulation. Annu Rev Cell Dev Biol 11: 441-469.

7. Li Z, Srivastava P (2004) Heat-shock proteins. Curr Protoc Immunol Appendix

8. Muchowski PJ, Wacker JL (2005) Modulation of neurodegeneration by molecular chaperones. Nat Rev Neurosci 6: 11-22.

9. Selkoe DJ (1999) Translating cell biology into therapeutic advances in Alzheimer's disease. Nature 399: A23-A31.

10. Selkoe DJ (2003) Folding proteins in fatal ways. Nature 426: 900-904.

11. Chen S, Brown IR (2007) Neuronal expression of constitutive heat shock proteins: implications for neurodegenerative diseases. Cell Stress Chaperones 12: 51-58.

12. Baranova EV, Weeks SD, Beelen S, Bukach OV, Gusev NB, et al. (2011) Three-dimensional structure of $\alpha$-crystallin domain dimers of human small heat shock proteins HSPB1 and HSPB6. J Mol Biol 411: 110-122.

13. Sarto C, Binz PA, Mocarelli $P$ (2000) Heat shock proteins in human cancer Electrophoresis 21: 1218-1226.

14. Charette SJ, Lavoie JN, Lambert H, Landry J (2000) Inhibition of Daxxmediated apoptosis by heat shock protein 27. Mol Cell Biol 20: 7602-7612.

15. Magrane J, Smith RC, Walsh K, Querfurth HW (2004) Heat shock protein 70 participates in the neuroprotective response to intracellularly expressed betaamyloid in neurons. J Neurosci 24: 1700-1706.

16. Dou F, Netzer WJ, Tanemura K, Li F, Hartl FU, et al. (2003) Chaperones increase association of tau protein with microtubules. Proc Natl Acad Sci U S A 100: 721-726.

17. Brown IR (2007) Heat shock proteins and protection of the nervous system. Ann N Y Acad Sci 1113: 147-158.

18. Wyttenbach A, Sauvageot O, Carmichael J, Diaz-Latoud C, Arrigo AP, et al. (2002) Heat shock protein 27 prevents cellular polyglutamine toxicity and suppresses the increase of reactive oxygen species caused by huntingtin. Hum Mol Genet 11: 1137-1151.
19. Wilhelmus MM, Boelens WC, Otte-Höller I, Kamps B, de Waal RM, et al. (2006) Small heat shock proteins inhibit amyloid-beta protein aggregation and cerebrovascular amyloid-beta protein toxicity. Brain Res 1089: 67-78.

20. Ding Q, Keller JN (2001) Proteasome inhibition in oxidative stress neurotoxicity: implications for heat shock proteins. J Neurochem 77: 10101017.

21. Lowenstein DH, Gwinn RP, Seren MS, Simon RP, Mclntosh TK (1994) Increased expression of mRNA encoding calbindin-D28K, the glucoseregulated proteins, or the $72 \mathrm{kDa}$ heat-shock protein in three models of acute CNS injury. Brain Res Mol Brain Res 22: 299-308.

22. Luo W, Dou F, Rodina A, Chip S, Kim J, et al. (2007) Roles of heat-shock protein 90 in maintaining and facilitating the neurodegenerative phenotype in tauopathies. Proc Natl Acad Sci U S A 104: 9511-9516.

23. Li CY, Lee JS, Ko YG, Kim JI, Seo JS (2000) Heat shock protein 70 inhibits apoptosis downstream of cytochrome $c$ release and upstream of caspase-3 activation. J Biol Chem 275: 25665-25671.

24. Wilhelmus MM, Otte-Höller I, Wesseling P, de Waal RM, Boelens WC, et al. (2006) Specific association of small heat shock proteins with the pathological hallmarks of Alzheimer's disease brains. Neuropathol Appl Neurobiol 32 . 119-130.

25. Perez N, Sugar J, Charya S, Johnson G, Merril C, et al. (1991) Increased synthesis and accumulation of heat shock 70 proteins in Alzheimer's disease. Brain Res Mol Brain Res 11: 249-254.

26. Hamos JE, Oblas B, Pulaski-Salo D, Welch WJ, Bole DG, et al. (1991) Expression of heat shock proteins in Alzheimer's disease. Neurology 41 : 345-350.

27. Castegna A, Aksenov M, Thongboonkerd V, Klein JB, Pierce WM, et al. (2002) Proteomic identification of oxidatively modified proteins in Alzheimer's disease brain. Part II: dihydropyrimidinase-related protein 2, alpha-enolase and heat shock cognate 71. J Neurochem 82: 1524-1532.

28. Abdul HM, Calabrese V, Calvani M, Butterfield DA (2006) Acetyl-L-carnitineinduced up-regulation of heat shock proteins protects cortical neurons against amyloid-betapeptide 1-42-mediated oxidative stress and neurotoxicity: implications for Alzheimer's disease. J Neurosci Res 84: 398-408.

29. Asea A, Rehli M, Kabingu E, Boch JA, Bare O, et al. (277) Novel signal transduction pathway utilized by extracellular HSP70: role of toll-like receptor (TLR) 2 and TLR4. J Biol Chem 277: 15028-15034.

30. Senf SM, Howard TM, Ahn B, Ferreira LF, Judge AR (2013) Loss of the inducible $\mathrm{Hsp} 70$ delays the inflammatory response to skeletal muscle injury and severely impairs muscle regeneration. PLoS One 8: e62687.

31. Renkawek K, Bosman GJ, de Jong WW (1994) Expression of small heatshock protein hsp 27 in reactive gliosis in Alzheimer disease and other types of dementia. Acta Neuropathol 87: 511-519.

32. May LA, Kramarenko II, Brandon CS, Voelkel-Johnson C, Roy S, et al. (2013) Inner ear supporting cells protect hair cells by secreting HSP70. J Clin Invest 123: 3577-3587.

33. Tytell M (2005) Release of heat shock proteins (Hsps) and the effects of extracellular Hsps on neural cells and tissues. Int J Hyperthermia 21: 445455.

34. Tonkiss J, Calderwood SK (2005) Regulation of heat shock gene transcription in neuronal cells. Int J Hypertherm 21: 433-434.

35. Giffard RG, Han RQ, Emery JF, Duan M, Pittet JF (2008) Regulation of apoptotic and inflammatory cell signaling in cerebral ischemia: the complex roles of heat shock protein 70. Anesthesiology 109: 339-348.

36. Guzhova I, Kislyakova K, Moskaliova O, Fridlanskaya I, Tytell M, et al. (2001) In vitro studies show that Hsp70 can be released by glia and that exogenous Hsp70 can enhance neuronal stress tolerance. Brain Res 914: 66-73.

37. Prahlad V, Morimoto RI (2009) Integrating the stress response: lessons for neurodegenerative diseases from C. elegans. Trends Cell Biol 19: 52-61.

38. Beere HM, Wolf BB, Cain K, Mosser DD, Mahboubi A, et al. (2000) Heatshock protein 70 inhibits apoptosis by preventing recruitment of procaspase- 9 
Citation: Najarzadegan MR, Ataei E, Akbarzadeh F, borhani M, Mokhber N, et al. The Role of Heat Shock Proteins in Alzheimer Disease: A Systematic Review. J Syndromes. 2016;3(1): 6.

ISSN: $2380-6036$

to the Apaf-1 apoptosome. Nat Cell Biol 2: 469-475.

39. Gupta S, Deepti A, Deegan S, Lisbona F, Hetz C, et al. (2010) HSP72 Protects cells from ER Stress-induced apoptosis via enhancement of IRE1 $\alpha$ XBP1 signaling through a physical interaction. PLoS Biol 8: e1000410.

40. Hoshino T, Murao N, Namba T, Takehara M, Adachi H, et al. (2011) Heat shock protein 70 stimulates beta-amyloid clearance. J Neurosci 31: 52255234.

41. McKhann G, Drachman D, Folstein M, Katzman R, Price D, et al. (1984) Clinical diagnosis of Alzheimer's disease: report of the NINCDS-ADRDA Work Group under the auspices of department of health and human services task force on Alzheimer's disease. Neurology 34: 939-944.

\section{Acknowledgements}

\section{Funding}

This study was supported with Behavioral Science Research Centre of Mashhad University of Medical Science, Mashhad, Iran. The authors had no conflict of interests and they approved this paper. 